\title{
Articles
}

\section{An Intercultural Curriculum for a Leadership in Community Engagement Program: Linking Theory and Practice}

Lorraine Mercer, Huntington University

Lorraine Carter, McMaster University

\section{Abstract}

Student diversity in Canadian universities is rapidly increasing, and faculty and curriculum developers are challenged to transform programs and pedagogies to meet the learning needs of diverse students. While universities across Canada are actively attending to the need for interculturality and diversity in undergraduate education, this same need exists in continuing education units that serve heterogeneous populations of adult learners. This paper explores the intercultural curricular experience in the context of adult education in two ways: (i) examining the literature that reviews key terms and concepts related to culture, interculturality, and learning, and (ii) drawing upon examples of intercultural learning based on a certificate

\section{Résumé}

La diversité des étudiants des universités canadiennes augmente rapidement. Les facultés et les concepteurs de programmes ont le défi de transformer les programmes et les pédagogies pour répondre aux besoins d'apprentissage des étudiants issus d'origines diverses. Tandis que les universités du Canada répondent activement aux besoins de l'interculturalité et de la diversité dans la formation de premier cycle, les mêmes besoins existent dans les unités de formation continue qui desservent des populations hétérogènes d'apprenants adultes. Cet article explore de deux façons l'expérience de programmes interculturels dans le contexte de l'éducation des adultes: (i) examiner la documentation qui revoit les termes et concepts essentiels 
program called Leadership in Community Engagement, offered by the Centre for Continuing Education at McMaster University in Hamilton, Ontario, Canada. We also offer recommendations for those working in adult and continuing education who strive for respectful and meaningful intercultural learning. liés à la culture, à l'interculturalité et à l'apprentissage, et (ii) utiliser des exemples d'apprentissage interculturel fondé sur un certificat intitulé Leadership in Community Engagement (Leadership en engagement communautaire) offert par le Centre for Continuing Education (Centre d'éducation continue) de I'Université McMaster à Hamilton, en Ontario, au Canada. Les auteurs offrent aussi des recommandations pour les intervenants de l'éducation permanente et de l'éducation pour adultes qui s'efforcent d'offrir un apprentissage interculturel respectueux et pertinent.

\section{Introduction}

The cultural diversity of students engaged in adult education is rapidly increasing. In Canada, this situation is due to multiple factors, including but not limited to patterns of globalization, Canada's federal immigration policy, and the country's growing Aboriginal youth population. As today's adult learners learn, live, and work together, the need for curricula that reflect cultures and relationships among cultures will only continue to grow (UNESCO, 2009). Inspired by the experiences of adult learners from various cultures and the work of instructors and instructional designers dedicated to teaching and learning in culturally meaningful ways, this paper explores intercultural curriculum development and practice in a university continuing education program serving adult learners. The paper also includes practice-based examples of these principles as demonstrated in a certificate program called Leadership in Community Engagement, offered by the Centre for Continuing Education at McMaster University. Grounded in an anti-racism, anti-oppression philosophy, the program serves adult learners in Hamilton and the surrounding area whose work involves intersection with one or more communities in this culturally rich part of Ontario. Called co-learners, the program participants come from all walks of life, different professional backgrounds, and mixed cultural identities.

The paper begins with limited conceptual discussions drawn from the literature, followed by brief accounts of how these ideas are integrated in the Leadership in Community Engagement program. The final section of the paper includes an integrated discussion of relevant synergies between the literature and the program and offers recommendations for continuing and adult education professionals involved in or considering similar programs. 


\title{
An Exploration of Theory and Practice
}

\author{
What Is an Intercultural Curriculum?
}

An intercultural curriculum is a planned program of study that, with the intentional inclusion of culturally diverse content explored in a safe learning environment, fosters cognitive and affective learning. The learning experience includes description, comparison, contextual understanding, and critical analysis of cultural content (Coulby, 2006). It is transformative in nature (Bleszynska, 2008; Mezirow, 2000). It also includes reflection on one's own and others' cultures, which in turn contributes to a response to culture (Crabtree \& Sapp, 2004; Tisdell \& Tolliver, 2009), identity formation, and empowerment (Dunne, 2011). It is likewise interactive and reciprocal (Crichton \& Scarino, 2007). An intercultural curriculum may be designed for both Canadian born and Canadian-by-choice students (Crose, 2011; Mak \& Kennedy, 2012; Ryan \& Carroll, 2005). Intercultural learning experiences can also occur in face-to-face and Internet-assisted courses such as online and blended learning courses (Bélisle, 2008; Guo \& Jamal, 2007; Kurubacak, 2011; Raffaghelli \& Richieri, 2010). Such curricula enable individuals to broaden their perspectives, develop multilayered understandings of ideas and practices, and respond to cultural diversity in general (INTER Project, 2007).

\section{What is a Leadership in Community Engagement Program with an Intercultural Focus?}

This 15-unit/credit program called Leadership in Community Engagement (LCE) is offered to working professionals in the urban setting of the City of Hamilton, Ontario. Its overarching purpose is to enable the development of relevant knowledge, skills, and attitudes to bring to the practice of community engagement. Building on the topics explored in an introductory course called Foundational Principles and Practices in Community Engagement, participants, who are called co-learners, may complete the following additional courses and earn a McMaster University academic certificate: Research and Evaluation; Communication and Conflict Management; The Facilitation of Collaborative Leadership. The final course in the program integrates theoretical concepts and practices from the four other courses and offers co-learners the opportunity to hone their emerging skills in community engagement by planning a community-based project. Bringing together individuals from City of Hamilton departments whose work includes one or more aspects of community engagement - the Hamilton Legal Clinic, the Hamilton-Wentworth Board, the YMCA, Ontario Works, and other community-oriented agencies and not-for-profit organizations - the program is distinguished by a multisectoral and multicultural lens in its learner group, course structures, and curricular issues.

The intercultural strategies and examples shared throughout this paper are derived from offerings of the courses in the program during the 2016-2017 academic year. 


\section{What is Culture?}

UNESCO provides a foundational definition for culture in an educational context: "In discussing culture, reference is made to all the factors that pattern an individual's ways of thinking, believing, feeling and acting as a member of society" (UNESCO, 2006). Importantly, it is not only ethnicity, race, gender, and age that form culture; class, nation of origin, religion, socioeconomic status, physical/mental disability, and sexual orientation and identity also play a role (Guo \& Jamal, 2009; Gurung, 2009; Mercer, 2017). Integral to thinking about culture and learning are a number of concepts that emerged in the 1980s and 1990s and that have been embraced as well as modified since their early days; they include terms such as multicultural, cross-cultural, cultural awareness, cultural competence, and cultural safety (Gundara \& Portera, 2008). More recently, the terms intercultural and cultural security have come of particular age. While the idea of an intercultural curriculum existed as early as the 1980s (Smith, 1983), today, it is a key focus in curricular discussions throughout Canada. The term cultural security represents a furthering of the idea of being safe in one's cultural identity in diverse settings. It is suggested that the contemporary political landscape in various countries around the world has brought cultural safety and security to the forefront in educational contexts.

\section{Bringing Theoretical Understandings of Culture to the LCE Program}

Interculturality is an integral element in the LCE program. While very few, if any, of the co-learners in the courses would be unfamiliar with the iterations of culture described above, where the course facilitators have identified a need for further learning is in acknowledging personal cultural and sociopolitical identities and understanding how these identities intersect with those of other participants in the program. As an example, in the first offering of the foundations course, the co-learners were invited to participate in an activity that identifies a person's level of social privilege relative to others'. While social power and privilege are tied to many variables, at their core are the cultures we belong to and through which we have experienced different life events.

The activity mentioned above led to what one stakeholder has referred to as microaggressions within the group. If such tendencies exist within a group of professionals committed to the betterment of their communities, it follows that in at least some instances, these tendencies may affect their work. Assuming that this may be the case, intercultural learning and practice are important not only for undergraduates but for adult and professional learners too. Opportunities for deep personal reflection and enhanced learning about group process when a group is mixed in terms of ethnicity, age, gender, and professional and socioeconomic background are recommended. So too are smaller classes than the one in which the activity occurred, which had over 50 co-learners. Since then, class size has been limited to 20 as it is much easier to build trust in smaller classes than larger ones. The means available to the 
facilitator to incite delicate conversations about culture and community in respectful ways are more plentiful in a smaller context than a larger one.

\section{Educational Theory and Intercultural Curriculum}

A number of educational theories are relevant to an understanding of intercultural curricula. These theories include constructivism, social constructivism, humanism, and experientialism.

\section{Constructivism}

Constructivism is prevalent in discussions of intercultural curriculum development. According to constructivist principles, learning is an active process through which students build knowledge by making connections with what they already know. Connections are made by communicating with others and through personal reflection (Merriam \& Brockett, 2007; Sweeney, 2012). The educator assists students in the active construction of their knowledge. The goal is for students to be active participants in the construction of their learning rather than passive recipients of the teacher's expert knowledge. For these reasons, constructivism is described as a learner-focused educational paradigm (Kemp, 2012; Tangney, 2014). In the constructivist school of thought, both teaching and curriculum design minimize learning by lecture and maximize active learning through student engagement with ideas (Noddings, 2012). Constructivist approaches include case-based learning, collaborative learning, engaged learning, problem-based learning, scaffolded learning, and team-based learning.

\section{Social constructivism}

A closely related school of thought is social constructivism. This theoretical orientation to learning is similar to the theoretical underpinnings of constructivism: it acknowledges that knowledge is constructed through connection and reflection with others in the learning environment (e.g., the classroom, a study session, an online discussion forum). In social constructivism, these connections take place through discourse and, specifically, through critical dialogue that challenges hegemonic discourses focused on dominant values and beliefs. As the father of educational and cultural thinking, Paulo Freire (1992) empowered poorly educated students to be invested in dialogue, engaged in critical thinking, active in the construction of their own expertise, and ready to challenge the status quo.

\section{Humanism}

Humanism underpins many of the learning theories associated with an intercultural curriculum. The tenets of these theories include the beliefs that humans are basically good, that they are autonomous beings with free will, and that they seek growth and fulfillment in life (Merriam \& Brockett, 2007). The aim of humanistic learning theory is development of the potential and wholeness of a person through cognitive and emotional strategies (Tangney, 2014). The 
learner's role is to take charge of his or her own learning, while the teacher's role is to foster opportunities for student learning (Bélisle, 2008).

\section{Experientialism}

Related to both humanism and constructivism is experiential learning theory, which recognizes the value of learning achieved outside of the classroom. Important in the 1960s and 1970s (Bertrand, 1995), experiential theory and practice are experiencing a revival in Canadian higher education. As an example, in the province of Ontario, the Ministry of Advanced Education and Skills Development is placing distinct emphasis on readiness for today's increasingly technological, mobile, and globally defined workplace. As such, experiential learning as a way of facilitating workplace readiness is garnering attention in many postsecondary programs.

\section{Final Thoughts about Theory}

While the theoretical perspectives previously discussed are not always acknowledged in the academic literature on intercultural curriculum, they are evident in the underpinning assumptions in the models, approaches, and case examples used in the design and implementation of intercultural curricula. Additionally, although no one learning theory has been identified as the best for intercultural curricula, a blend of humanism and constructivism emerges as most appropriate. This observation is explored in the subsequent discussion of learning about community and culture in the Leadership in Community Engagement program.

\section{The Educational Theories Prevalent in the LCE Program}

Each of the above theories has found a home in the LCE program. Because the program involves adult learners, it should not be surprising that constructivism is the prevalent theory. Adults come to their classes and courses with much prior knowledge as well as much work and life experience that they use to construct and reconstruct new knowledge and skills. Such is the case for the co-learners in the LCE program. The primary way by which construction and relationality occur in the program is discourse, the hallmark of social constructivism. Finally, in the tradition of Freire (1992), the program includes persons from all educational levels-master's degrees to high school education. All voices have a place at the discourse table, and each co-learner is encouraged to think critically and share openly to discover ways of transforming limiting and/or problematic systems and solve wicked social and community problems.

While the tenets and practices of constructivism and social constructivism are dominant in the program, transmissive learning, not previously discussed, also plays a role. At different times, the co-learners have asked for direct teaching of particular concepts and for "taking up of guided reading questions" for assigned readings. They have likewise expressed considerable 
favour for expert talks. Panels have been well received as a way to learn about different perspectives on controversial issues from experts, including those with lived experience.

Humanism and experientialism are equally prevalent in the LCE program. Despite the professional and personal differences among the co-participants, there is a common thread in the group's thinking - that the social determinants of health, including cultural identity and social capital, impact our lives in profound ways. For example, it is well documented in the health literature how the social variables in our lives affect health and well-being. Persons with strong social supports and solid socioeconomic status live longer than those without such advantages. By comparison, experientialism is present in every course in that the co-learners bring their experiences of culture and community to their classes. The final course in the program is a capstone course through which the co-learners engage in a community project and document their learning as the project unfolds.

\section{Awareness and Reflection}

Broadly speaking, there are three elements to learning in an interculturally focused curriculum: (1) awareness of one's personal values and beliefs; (2) awareness of the values and beliefs of one's cultural group; and (3) awareness of the values and beliefs of another culture. When a person has acquired these three kinds of awareness, he or she generally has a clearer sense of identity than otherwise. Importantly, this identity is situated in relation to the identities of others.

As a number of scholars have identified, reflection is fundamental to the development of the student's and the teacher's cultural awareness (Gravett \& Peterson, 2009; Jones, 2009; Marginson \& Sawir, 2011; Taylor, 2009). While many scholars have defined reflection and its processes, Mestenhauser (1998), an early scholar in the field, offers a particularly useful description of the process of reflection in relation to culture: students learn about culture through an etic perspective, or observation of another culture. At the same time, they can learn by means of an emic perspective, involving observations from within their own cultures. Flexibility in thinking develops when the learner engages with the two perspectives in an iterative process of comparing and experiencing two cultures.

\section{Awareness and Reflection in the LCE Classroom}

One of the greatest benefits the program affords the co-learners is time for reflection and self-awareness. In day-to-day work, many persons lack the time and possibly the tools they need to practise reflection, determine motivations, evaluate strengths and weaknesses, and make thoughtful plans. In the LCE program, however, each course includes formal and informal occasions for reflection and, by extension, critical thinking (Carter \& Ruckholm, 2008). Co-learners are challenged not only by the core elements in the curriculum but also by their culturally diverse classmates and the course facilitator. 
Such engagement occurs in face-to-face classes as well as those facilitated online. Notably, since the early days of research in online education, there has been evidence that the reading and writing aspects of online learning can enhance learner thoughtfulness (Carter \& Rukholm, 2008). In the LCE program, all facilitators are selected for their academic and experiential knowledge and their skill in encouraging respectful and inclusive discourse in diverse learning settings. Further, they are willing, as appropriate, to meet with co-learners outside of class time.

The different cultural identities of the co-learners and the overarching theme of intercultural thinking and practice challenge participants to push beyond their personal and professional boundaries. As noted earlier, the co-learners come from varied professional settings, including the school board, the public library, the legal community, the city's community development sector, and other not-for-profit agencies.

\section{Words of Caution about Intercultural Curricula: Relativism and Critical Awareness}

Learning about culture and culture as community has distinct challenges for the student and the teacher. The first pertains to readiness for relativism, while the second involves the consequences of having a critical awareness of culture.

Readiness for relativism refers to the tendency of individuals to take the path of the relativist and to accept all differences rather than make informed judgments when faced with cultural values and practices other than their own (Heale, 1999). Curricula need to be designed to challenge biases, values, and generalizations and to avoid unexamined acceptance of differences or reified perspectives (Tupas, 2014). Students develop authentic appreciation of cultures only if these cultures are critically examined and understood (Walton, Priest, \& Paradies, 2013).

In contrast with readiness for relativism is the challenge of supporting students' critical awareness of their own cultures and identities. Learning about a culture is sometimes a shock, followed by a slow process of absorption of a realization; it takes time to make sense of the impact of such a realization and to work through a process of appropriation and renegotiation (Claxton, Pollard \& Sutherland, 2003). Learning in cultures and communities that are different from one's own is associated with shifts in identity, the development of bicultural identity, and sensitization to differences (Bleszynska, 2008).

Critical awareness is achieved when a deeper level of understanding is reached, and the individual realizes that his or her way of seeing is just one of many ways. While this kind of awareness is found in the literature dealing with the identity issues of international students (Claxton et al., 2003), it is equally important in the adult education context. When adults engage in learning where beliefs and past practices are challenged, they must renegotiate their personal and professional affiliations and values. The process can be painful, but ultimately, it is a rewarding experience (Claxton et al., 2003). Given the complexity of this process, teachers, 
curricular elements, and the institution itself must be aligned to provide supportive learning environments for students.

\section{Words of Caution about the LCE Program: Relativism and Critical Awareness}

Relativism is a danger for learners at all levels, from elementary and secondary to college and university to adult education contexts such as the LCE program. Just as younger learners can be inclined to accept ideas rather than think them through at a deep level, the same can be said of adult learners. So long as an alternate view or practice seems to make sense in a specific culture, the adult may be disinclined to challenge elements of the culture that might otherwise conflict the person. While respect and inclusion are always core elements in the LCE program, facilitators and other co-learners have also found themselves engaged in delicate, and at times difficult, conversations with other members of the class who may have accepted ideas and practices simply because they exist within the norms of a particular culture.

In addition to the breadth and depth of the content dealing with community engagement in professional practice, a further reason that the program is a longer course-based one rather than a series of workshops is that it takes time for attitudes and values to change and consolidate. This idea is supported in the critical thinking literature, in which there is evidence that skills such as analysis and synthesis often develop more quickly than critical dispositions or habits of mind. Thus, while a workshop series can facilitate rapid learning, it may or may not provide sufficient time for participants to think deeply and possibly adjust their values and beliefs.

A particularly valuable learning experience was presented to the co-learners in the original offering of the principles and foundations course. During the session, the group explored ideas and concepts related to self-awareness, empathy, communication, and different ways of knowing, through interactions with visual art. The sessions were held in three different locations, thereby introducing the co-learners to the role that place has in our understandings of interactions. Significantly, the feedback provided by the co-learners about this aspect of the course was exceptionally positive.

\section{Cultural Safety and Cultural Security}

Cultural safety and cultural security go beyond traditional ideas of cultural awareness, sensitivity, and competency, and involve the acknowledgement of and response to power differentials in learning environments. This type of safety is often addressed in the nursing and healthcare literature where, through identification of differences in power, healthcare professionals are challenged to make changes in their practice and to advocate for changes in the health system through education of the self, the patient, and the system (Aboriginal Nurses Association of Canada, 2009). Power differentials are also prevalent in the higher education system, 
including in on-campus and online classrooms. This power differential is part of what is called the hidden curriculum, through which students may be disempowered in their learning.

At the core of the development of intercultural curriculum is the challenge of uncovering all hidden curriculum on culture (Dunne, 2011; Guo \& Jamal, 2007). Hidden curriculum is defined as unstated assumptions or rules that are in play but not necessarily articulated in a course, program, or institution. Students learn the unofficial rules about power and structure needed to succeed in the academic environment. The hidden curriculum pertaining to culture typically means that mainstream culture is a natural and fitting lens for learning. The knowledge, values, and experiences of the non-mainstream cultures are hidden. Teachers and learners can take responsibility for making the underpinning assumptions of the curriculum visible. This co-discovery of limitations and assumptions can be empowering for learners and teachers alike. Suggested strategies for meeting this responsibility include: being transparent about the intentions of creating a culturally safe or culturally secure classroom or online discussion space; modelling language of inclusion; and supporting student participation (Gurung, 2009). These strategies may lead to the discovery and confrontation of hidden assumptions and contribute to culturally safe or culturally secure environments. Taken a step further, rationalizing one's choice of how teaching and learning occur is theoretically just as significant as rationalizing one's choice of what is being taught and learned.

\section{Cultural Safety and Cultural Security in Practice}

Achieving the full spectrum from cultural awareness to cultural security is an important aim of the LCE program. More significantly, this aim is not a situation of tokenism. Although co-learners and facilitators are challenged and pushed beyond their personal boundaries, the setting is always respectful and safe. This is not to say, however, that some co-learners may not feel some discomfort with certain content and particular learning activities. Among his or her other duties, the facilitator is required to ensure a safe place for the exchange of ideas and opinions.

Some discomfort was expressed in the first offering of the first course for two reasons: the majority of co-learners had been selected by their employers to attend, and in some cases, a senior person from the workplace was also a co-learner. This situation was not ideal for some co-learners who had come to the course without enough information and perhaps did not want to be there. In addition, having senior staff members from the employers created a conundrum for some learners as well: were they to be themselves in their thinking and actions or were they to think like employees? The presence of employer representatives may have been perceived as a form of hidden curriculum. Since the first offering of the course, co-learners have self-selected to study, and there has been no employer presence in any subsequent courses. 


\section{Scaffolding in an Intercultural Curriculum}

Key theoretical and conceptual understandings in an intercultural learning context need to be accompanied by relevant course design and learning strategies. Scaffolding is particularly important in course and program design in that it includes planned supports for learning. It does not, however, refer to building course content; rather, it refers to building learning capacity through activities that support learning. As a practice, scaffolding can be used in face-toface, blended, and online learning settings (Salyers, Carter, Cairns, \& Durrer, 2014).

In the process of developing an intercultural curriculum, scaffolding may progress from understanding one's own culture to understanding a different culture to understanding how the members of a different culture perceive their culture. In work on intercultural training from its early days but that still resonates today, Spodek (1983) asserted that while learning the details of a culture (e.g., language, rituals, geography) and its frameworks (e.g., patterns, structures, roles) provides important foundation, comparing these elements with one's own culture fosters intercultural understanding and empathy. Students develop an understanding of the complexity of cultural systems, intercultural relations, and their own locations within this complexity (Spodek, 1983). In practice, scaffolding takes a student from learning about a culture to learning to enjoy other cultures and, finally, to learning how to interact with others of another culture.

\section{Teacher modelling}

Teacher modelling is one of the most common scaffolding strategies used in classroom instruction. Modelling may involve telling students what is happening in the process of thinking through an idea or task. It also involves demonstrating characteristics such as openness, curiosity, inclusiveness, and appreciation of cultural diversity (Tisdell \& Tolliver, 2009). The strategy in this case is for the teacher to be transparent as to how and why inclusivity and openness to culture are critical aspects of the learning environment.

In online education, teacher modelling can be extended and mediated by the technologies, resources, and opportunities for communication available to learners and teachers. The burgeoning literature on online education offers examples of learning experiences coupled with relevant supports that assist students in learning about other cultures; in such courses, baseline assessments, printed materials, videotaped model interviews, quizzes, and access to an instructor are some of the ways that cultural and intercultural learning is enabled (Nelles, Smith, Lax, \& Russell, 2011). Teacher modelling can occur in video-based interviews, which are valuable means of demonstrating appropriate communication across and between cultures. Additional scaffolding can occur through complicated case examples that build on cognitive knowledge and provide supports through expert responses and comments. 


\section{Building on the social nature of learning}

Scaffolded learning is often associated with collaboration, which requires relationships among students, teachers, content, and the process created for learning. In intercultural learning, students need to be social; they are required to share their knowledge of culture with one another, reflect, and respond within the learning environment. The social nature of learning was first identified by Vygotsky (1978), who proposed the concept of the zone of proximal development. This zone is not a physical space; it is a relational space between and among students and teachers. In that space, learning may occur beyond what individuals may learn on their own. This more expanded learning occurs through dialogue and exchange with others (Vygotsky, 1978). Social interaction is significant to the learning process and includes the students, peers, experts, and teachers.

\section{Scaffolding and Other Key Elements in the LCE Classroom}

In the case of the LCE program, considerable time was taken by a group of subject matter experts from the university and the Hamilton Community Foundation to select the topics, activities, and assessment strategies for each course. The same group made recommendations about how the facilitators might scaffold the learning environment, with an awareness that facilitators always need to use their judgement and bring flexibility to their courses. Just as scaffolding works across the program as co-learners progress from learning foundational principles to the challenging content of evaluation and community-based research to the final praxis-based project course, it also exists within individual courses. Readings, activities, talks, and discussions unfold in a quasi-progressive fashion, challenging learners to think and respond to ideas and cases with increasing complexity. Scaffolding is also apparent in the courses, given that four of the five are designed as blended courses. As such, judicious decisions are required so that meaningful learning continues during weeks when the co-learners do not meet for face-to-face learning.

In addition, great care was - and continues to be-taken in the selection of course facilitators. In all cases, facilitators possess a unique expertise that blends academic credentiality with "street cred." As such, they are able to meet participants at the various points along the learning journey and foster trust: they have made this same journey. The academic expertise of the facilitator team brings value to a field that others may or may not consider a professional field. As for "street cred," there is simply no substitute for it.

The facilitators model the values that underscore the program and possess skill in navigating delicate discussions. They are open to being challenged and to challenging the co-learners. Further, each facilitator is an experienced adult educator who respects the competing duties of the co-learners as they balance work, family, community, and learning responsibilities.

Regarding what the literature calls the social nature of learning, it is a key element in the classroom. Co-learners are active participants in their own learning and that of their peers. Through 
discourse-based activities and shared professional insights, the co-learners are active enablers of learning.

\section{Discussion}

An interculturally focused curriculum represents a valuable means of fostering transformative learning and, ideally, social change. It engages both the cognitive and the affective dimensions of the individual, and it takes place with other learners. The combination of reflection, awareness, and critical dialogue in a culturally secure learning environment empowers individuals to move beyond the learning of content to engaging with a community of learners. As such, the learning experience is a context for the discovery and practice of community leadership and engagement.

In the program described in this paper, learners experience their own cultural identities in relationship to the cultural identities of others. Through learning processes such as critical awareness and critical dialogue, power differentials and value conflicts with other learners are made evident and lead stakeholders to respectful understandings. Indeed, challenging dynamics provide important opportunities for leadership development, especially in areas such as communication, conflict management, and group process.

Just as value-laden thinking and anti-racist, anti-oppressive learning processes are essential in programs such as the LCE program, so too are the facilitators. When the facilitator models inclusion, openness, and curiosity about diversity and establishes a safe learning environment, learners are willing to take risks and move forward in their development as community leaders. The subject matter experts who recommend content choices and relevant course learning activities are likewise important. Consider the examples provided in this paper of what happens in LCE courses: discussions of power and privilege, interactions with visual art, panels with speakers expressing divergent perspectives, analyses of socially challenging issues, and real-life engagement with the community through community-based research and projects. Among other things, these examples illustrate the creativity and humanity of intercultural learning and leadership development programming for persons who work in communities.

In summary, curriculum is a powerful organizational tool for sharing theoretical and livedexperience knowledge and for enabling learning. In this paper, the complexities of an intercultural curriculum serving the learning needs of adult learners who work in diverse communities have been explored. Further, application of relevant theoretical constructs from the intercultural learning literature to the LCE program has illustrated how principle informs practice and how practice refines principle. This finding is embedded in the following recommendations, which are offered for adult educators interested in developing programs that reflect social accountability, respect for self and others, and a spirit of diversity and inclusion. 
1. When working with a culturally diverse group of adult learners, including professionally and socioeconomically diverse students, provide opportunities for deep personal reflection and enhanced learning about group process.

2. Limit class sizes to approximately 20 students to build trust and to establish a culturally safe learning environment.

3. Encourage critical thinking and open discussion on limiting and/or problematic systems and wicked social and/or community problems.

4. From time to time, include lecture-based teaching on key concepts and invite lecturers and panelists with expertise on relevant topics.

5. Provide regular opportunities for reflection and the exchange of ideas and experiences.

6. Carefully select facilitators with skills and attitudes consistent with intercultural learning. Facilitators need to be able to sustain respectful and inclusive discourse and be available to meet with students outside of class time.

7. Provide a program that occurs over time so that students can process and negotiate their cultural identities and values. A weekend workshop is not recommended for intercultural learning.

8. Include engagement with varied art mediums as a means to self-awareness, empathy, and communication.

9. Whenever possible, ensure that the composition of the co-learner group reflects the diversity of the community itself.

10. Welcome formative feedback and be prepared to make changes as course experience unfolds.

\section{References}

Aboriginal Nurses Association of Canada. (2009). Cultural competence and cultural safety in First Nations, Inuit and Métis nursing education: An integrated review of the literature. Ottawa, ON: Aboriginal Nurses Association of Canada.

Bélisle, C. (2008). eLearning and intercultural dimensions of learning theories and teaching models. Sciences de l'Homme et de la Société. Retrieved from https://halshs.archives-ouvertes.fr/halshs-00264330

Bertrand, Y. (1995). Contemporary theories and practice in education. Madison, WI: Magna Publications.

Bleszynska, K. M. (2008). Constructing intercultural education. Intercultural Education, 19(6), 537-545. doi:10.1080/14675980802568335 
Carter, L., \& Rukholm, E. (2008). A study of critical thinking, teacher-student interaction, and discipline-specific writing in an online educational setting for registered nurses. Journal of Continuing Education in Nursing, 39(3), 133-138.

Claxton, G., Pollard, A., \& Sutherland, R. (2003). Fishing in the fog: Conceptualizing learning at the confluence of cultures. In R. Sutherland, G. Claxton \& A. Pollard (Eds.), Learning and teaching: Where worldviews meet (pp. 1-18). Stirling, VA:Trentham Books.

Coulby, D. (2006). Intercultural education: Theory and practice. Intercultural Education, 17(3), 245-257. doi:10.1080/14675980600840274

Crabtree, R. D., \& Sapp, D. A. (2004). Your culture, my classroom, whose pedagogy? Negotiating effective teaching and learning in Brazil. Journal of Studies in International Education, 8,(1), 105-132.

Crichton, J., \& Scarino, A. (2007). How are we to understand the "intercultural dimension"? An examination of the intercultural dimension of internationalisation in the context of higher education in Australia. Australian Review of Applied Linguistics, 30, 4-25.

Crose, B. (2011). Internationalization of the higher education classroom: Strategies to facilitate intercultural learning and academic success. International Journal of Teaching and Learning in Higher Education, 23(3), 388-395.

Dunne, C. (2011). Developing an intercultural curriculum within the context of the internationalisation of higher education: Terminology, typologies and power. Higher Education Research \& Development, 30(5), 609-622. doi:10.1080/07294360.2011.598451

Freire, P. (1992). Pedagogy of the oppressed. New York, NY: The Continuum Publishing Company. (Original work published 1970)

Gravett, S., \& Peterson, N. (2009). Promoting dialogic teaching among higher education faculty in South Africa. In J. Mezirow \& E. W. Taylor (Eds.), Transformative learning in practice: Insights from community, workplace, and higher education (pp. 100-110). San Francisco, CA: Jossey-Bass.

Guo, S., \& Jamal, Z. (2007). Cultural diversity and inclusive teaching. London, ON: Society for Teaching and Learning in Higher Education.

Guo, S., \& Jamal, Z. (2009). Nurturing cultural diversity in higher education: A critical review of selected models. The Canadian Journal of Higher Education, 37(3), 27-49.

Gundara, J. S. \& Portera, A. (2008). Theoretical reflections on intercultural education. Intercultural Education, 19(6), 463-468. doi: 10.1080/14675980802568244

Gurung, R. A. R. (2009). Got culture? Incorporating culture into the curriculum. In R. A. R. Gurung \& L. R. Prieto (Eds.), Getting culture: Incorporating diversity across the curriculum (pp. 11-22). Sterling, VA: Stylus Publishing. 
Heale, V. (1999). Our culture, their culture: The interdisciplinary path to cross-cultural study. In M. B. Seabury (Ed.), Interdisciplinary general education: Questioning outside the lines (pp. 273-287). New York, NY: The College Entrance Examination Board.

INTER Project. (2007). Culture is our focus, diversity is our normality: INTER guide to implement intercultural education (Vol. 4, 2nd ed.). European Commission's Cormenius Programme. Vienna, Austria: Navreme Publications.

Jones, G. (2009). Internationalization and higher education policy in Canada: Three challenges. In R. D. Trilokekar, G. A. Jones, \& A. Shubert (Eds.), Canada's universities go global (pp. 355-369). Toronto, ON: James Lorimer \& Company.

Kemp, S. J. (2012). Exploring the use of learner-focused teaching approaches in different academic disciplines. Journal of Further and Higher Education, 37(6), 804-818. doi:10.1080/03 09877X.2012.684041

Kurubacak, G. (2011). eLearning for pluralism: The culture of eLearning in building a knowledge society. International Journal on E-Learning, 10(2), 145-167.

Mak, A. S., \& Kennedy, M. (2012). Internationalising the student experience: Preparing instructors to embed intercultural skills in the curriculum. Innovation in Higher Education, 37, 323-334. doi:10.1007/s10755-012-9213-4

Marginson, S., \& Sawir, E. (2011). Ideas for intercultural education. New York, NY: Palgrave MacMillan.

Mercer, L. (2017). Intercultural gerontology curriculum: Principles and practice. Gerontology and Geriatrics Education, 1-22. doi:10.1080/02701960.2017.1311885

Merriam, S. B., \& Brockett, R. G. (2007). The profession and practice of adult education: An introduction. San Francisco, CA: John Wiley \& Sons.

Mestenhauser, J. A. (1998). Portraits of an international curriculum: An uncommon multidemensional perspective. In J. A. Mestenhauser \& B. J. Ellingboe (Eds.), Reforming the higher education curriculum: Internationalizing the campus (pp. 3-39). Phoenix, AZ: The American Council on Education \& the Oryx Press.

Mezirow, J. (2000). Learning to think like an adult: Core concepts of transformation theory. In J. Mezirow \& Associates (Eds.), Learning as transformation: Critical perspectives on a theory in progress (pp. 3-33). San Francisco, CA: Jossey-Bass.

Nelles, L. J., Smith, C. M., Lax, L. R., \& Russell, L. (2011). Translating face-to-face experiential learning to video for a web-based communications program. The Canadian Journal for the Scholarship of Teaching and Learning, 2(1), 1-13. doi:10.5206/cjsotl-rcacea.2011.1.8

Noddings, N. (2012). Philosophy of education (3rd ed.). Boulder, CO: Westview Press.

Raffaghelli, J. E., \& Richieri, C. (2010). A classroom with a view: Net-based strategies to promote intercultural education. In L. Dirckinck-Holmfeld, V. Hodgson, C. Jones, M. de Laat, D. McConnell, \& T. Ryberg (Eds.), Proceedings of the Seventh International Conference on 
Networked Learning. Lancaster, UK: Lancaster University. Retrieved from https://www. researchgate.net/publication/260069275_A_classroom_with_a_view_Net-based_strategies_to_promote_intercultural_education

Ryan, J., \& Carroll, J. (2005) Canaries in the coal mine: International students in Western universities. In J. Ryan \& J. Carroll (Eds.). Teaching international students: Improving learning for all (pp. 3-10). New York, NY: Routledge.

Salyers, V., Carter, L., Cairns, S., \& Durrer, L. (2014). The use of scaffolding and interactive learning strategies in online courses for working nurses: Implications for adult and online education. Canadian Journal of University Continuing Education, 40(1), 1-20. doi:10.21225/ D59S3Z

Smith, E. J. (1983). Canadian multiculturalism: The solution or the problem? In D. Landis \& R. W. Brislin (Eds.), Handbook of intercultural training (Vol.III). Area studies in intercultural training (pp. 260-275). Toronto, ON: Pergamon Press.

Spodek, H. (1983). Integrating cross-cultural education in the postsecondary curriculum. In D. Landis \& R. W. Brislin (Eds.), Handbook of intercultural training (Vol. III). Area studies in intercultural training (pp. 81-101). Toronto, ON: Pergamon Press.

Sweeney, L. J. (2012). Education. In L. L'Abate (Ed.). Paradigms in theory construction (pp. 125145). New York, NY: Springer.

Tangney, S. (2014). Student-centred learning: A humanist perspective. Teaching in Higher Education, 19(3), 266-275. doi:10.1080/13562517.2013.860099

Taylor, E. W. (2009). Fostering transformative learning. In J. Mezirow \& E. W. Taylor (Eds.), Transformative learning in practice: Insights from community, workplace, and higher education (pp. 3-17). San Francisco, CA: Jossey-Bass.

Tisdell, E. J., \& Tolliver, D. E. (2009). Transformative approaches to culturally responsive teaching: Engaging cultural imagination. In J. Mezirow \& E. W. Taylor and Associates (Eds.), Transformative learning in practice: Insights from community, workplace, and higher education (pp. 89-99). San Francisco, CA: Jossey-Bass.

Tupas, R. (2014). Intercultural education in everyday practice. Intercultural Education, 25(4), 243-254. doi:10.1080/14675986.2014.883166

UNESCO. (2006). UNESCO guidelines on intercultural education. Retrieved from http:// unesdoc.unesco.org/images/0014/001478/147878e.pdf

UNESCO. (2009). Investing in cultural diversity and intercultural dialogue. Retrieved from http:// www.unesco.org/library/PDF/Diversity.pdf

Vygotsky, L. S. (1978). Mind in society: The development of higher psychological processes. M. Cole (Ed.). Cambridge, MA: Harvard University Press. 
Walton, J., Priest, N., \& Paradies, Y. (2013). Identifying and developing effective approaches to foster intercultural understanding in schools. Intercultural Education, 24(3), 181-194. doi:1

$0.1080 / 14675986.2013 .793036$

\section{Biographies}

Lorraine Mercer is an associate professor in gerontology and in religious studies at Huntington University in Sudbury, Ontario. She is also the director of the Lougheed Teaching and Learning Centre at Huntington University.

Lorraine Mercer est professeure adjointe en gérontologie et en études religieuses à I'Université Huntington de Sudbury, en Ontario. Elle dirige également le Lougheed Teaching and Learning Centre (Centre d'enseignement et d'apprentissage Lougheed) de cette même université.

Lorraine Carter is the director of the Centre for Continuing Education at McMaster University in Hamilton, Ontario. She is a leading contributor to the growing body of research in the area of online, distance, and blended learning.

Lorraine Carter est la directrice du Centre for Continuing Education (Centre d'éducation continue) de l'Université McMaster à Hamilton, en Ontario. Elle est une collaboratrice de premier plan au corpus croissant de recherche dans le domaine de l'apprentissage en ligne, à distance et mixte. 